М.А. Андрейчин

\title{
МОРОЗОВА Н.С., МАРІЕВСЬКИЙ В.Ф. ДЕЗІНФЕКТОЛОГІЯ. СТЕРИЛІЗАЦІЯ, ДЕЗІНСЕКЦІЯ, ДЕРАТИЗАЦІЯ: ПІДРУЧНИК ДЛЯ СТУДЕНТІВ ВИЩИХ НАВЧАЛЬНИХ ЗАКЛАДІВ МЕДИЧНОГО ПРОФІЛЮ. - К.: НАУКОВА ДУМКА, 2019. - 240 с.
}

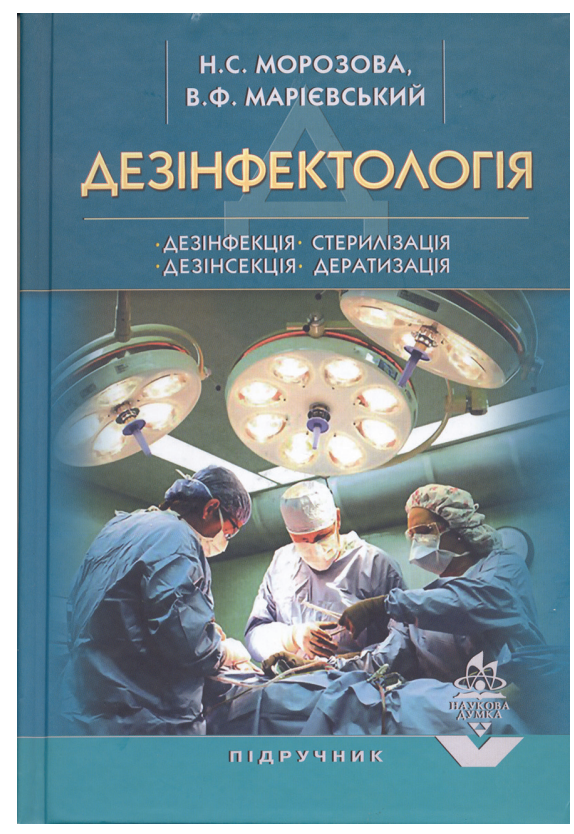

Проблема інфекційних хвороб зберігає свою актуальність у світі та, зокрема, в Україні. Попри значні успіхи інфектології тривають пандемії туберкульозу, вірусних гепатитів і ВІЛ-інфекції. Все частіше заявляють про себе старі інфекції, в тому числі керовані засобами специфічної імунопрофілактики. Збільшується число нових інфекцій, які раніше не виявлялися або ж займали обмежену ендемічну територію.

Однак підручника з дезінфректології в Україні досі не було, хоча ця наука продовжує розвиватися і має неабиякі практичні досягнення. Тому вихід у світ рецензованої книжки треба вітати. Тим більш, що авторами є відомі епідеміологи профресори Н.С. Морозова і В.Ф. Марієвський, знані своїм науковим доробком в цій важливій ділянці медицини.

Підручник складається з чотирьох частин, що відображають основні складові дезінфектології. У розділі 1 «Дезінфекція» послідовно викладено сучасні відомості про види і фрорми, засоби і способи дезінфекції, контроль її якості, дезінфекційні камери, апарати й установки.
Розділ 2 «Стерилізація» містить найважливіші дані про достерилізаційну підготовку виробів медичного призначення та контроль якості цієї роботи, фрізичні та хімічні методи стерилізації, а також контроль якості стерилізації за допомогою інструментальних, хімічних і біологічних способів.

У розділі 3 «Дезінсекція» описано ії фрізичні та хімічні методи, основні інсектициди та їх синергісти, інгібітори хітиноутворення, аналоги ювенільного гормону комах, репеленти та атрактанти. Наведено теперішню класифрікацію інсектицидів за хімічним складом, сучасне уявлення про резистентність членистоногих до цих препаратів, подразливість членистоногих інсектицидами. Окремо виділено умови роботи з інсектицидними засобами та техніку безпеки, заходи боротьби з окремими видами членистоногих (воші, блохи, кровосисні двокрилі комахи - комарі, мошки, мокриці, ґедзі, москіти, синантропні таргани, мурашки, кліщі, блощиці, мухи).

Розділ 4 «Дератизація» містить дані про організаційні основи боротьби з гризунами; інтегровану систему керування чисельністю тварин-шкідників; синантропію гризунів; їх медичне і господарське значення; заходи, методи і засоби дератизації, санітарно-профрілактичні та винищувальні; вжиття заходів проти гризунів на об'єктах різного господарського призначення; зниження чисельності гризунів у їхніх змішаних поселеннях в околицях населених пунктів; контроль якості та оцінювання ефективності дератизації.

Текстову частину кожного розділу ілюструють численні таблиці та рисунки, що полегшують сприйняття навчального матеріалу. У додатках короткий «Словник термінів і визначень» і список рекомендованої літератури до кожного розділу підручника.

У цілому підручник справляє позитивне враження продуманою структурою та вмілою подачею багатого фактичного матеріалу . Безперечно, він допоможе підвищити якість навчального процесу. Проте одночасне призначення його для студентів медичних вишів, коледжів і профрільних фахівців, на нашу думку, не зовсім обґрунтоване. У подальшому для кожної з цих категорій читачів доцільно створити 
окремий підручник чи навчальний посібник, з врахуванням рівня їх підготовки і вимог сучасних навчальних програм. При перевиданні підручника бажано більше уваги приділити висвітленню теоретичних основ дезінфектології, творчих традицій ї досягнень наших корифеїв епідеміолоriï.

\section{Відомості про автора:}

Андрейчин Михайло Антонович - академік НАМНУ, профресор, д. мед. н., завідувач касредри інсрекційних хвороб з епідеміологією, шкірними і венеричними хворобами Тернопільського національного медичного університету ім. І.Я. Горбачевського; andreychyn@tdmu.edu.ua

\section{Information about author:}

Andreychyn M.A. - academician of the National of Medical Sciences of Ukraine, Professor, MD, Head of the Infectious Diseases and Epidemiology, Skin and Venereal Illnesses Department of I. Horbachevsky Ternopil National Medical University; andreychyn@tdmu.edu.ua

Конфрлікт інтересів: немає.

Author has no conflict of interest to declare.

Отримано 28.05.2019 р.

\section{ВЕЛЬМИШАНОВНІ КОЛЕГИ!}

Запрошуємо Вас взяти участь у роботі Всеукраїнської науково-практичної конореренції і пленуму Всеукраїнської асоціації інфрекціоністів на тему: «Діагностика, лікування і профрілактика інфрекційних хвороб у період медичної реформи», які відбудуться 3-4 жовтня 2019 року в м. Кропивницький в актовій залі Медичного коледжу м. Кропивницький за адресою: вул. Студентський бульвар, 16, м. Кропивницький.

Всеукраїнську науково-практичну конференцію внесено до Реєстру з'їздів, конгресів, симпозіумів та науково-практичних конференцій, що проводяться у 2019 році МОЗ і НАМН України (№ 302). Запрошення від оргкомітету, згідно з вимогами чинних директивних документів, є підставою для відрядження.

\section{Контактні телефони для довідок:}

Президент Всеукраїнської асоціації інфекціоністів академік НАМНУ, профр. Михайло Антонович Андрейчин - тел. служб. (0352) 52-47-25;

Секретар правління Всеукраїнської асоціації інфекціоністів, доцент Олег Любомирович Івахів - тел. моб.: 050-377-59-85; 068-941-89-17.

E-mail: olivakhiv@ukr.net aбо infecdis@ukr.net 